\title{
MAGMA DETECTIVES: STUDYING VOLCANIC ARCS TO FIND VALUABLE MINERALS IN EARTH'S CRUST
}

MINING COMPANIES ARE HAVING TO LOOK DEEPER IN THE EARTH'S CRUST FOR COPPER AND OTHER PRECIOUS METALS, BUT HOW DO THEY KNOW WHERE TO LOOK? SCIENTISTS WORKING ON THE FAMOS RESEARCH PROJECT ARE SEARCHING FOR CLUES IN THE MINERALS FORMED IN THE MAGMA PLUMBING SYSTEMS OF ANCIENT VOLCANOES

\section{REY FACT}

Ores - Naturally-occurring chemical compounds (or minerals) that are rich in metals. Most of the common metal ores are sulphides and oxides. For example, chalcopyrite is a sulphide of copper and iron, and is the principal source of copper worldwide. Ores form in "traps" in the Earth's shallow crust.

For a description of how metals are extracted, check out GCSE Science's 'Extraction of Metals':

http://www.gcsescience.com/ex1.htm

Mining companies are finding it increasingly difficult to search for ore deposits. This is because most of the easily accessible deposits in the Earth's shallow crust have already been discovered. Modern society is very much reliant on metals: for example, gold, lithium, aluminium, cobalt and copper are just some of the metals you'll find in your mobile phone. If ore deposits are becoming harder to find, how will manufacturers source the metals that are necessary to produce the technologies we use and need?

Prof Jamie Wilkinson is a geochemist working at the Natural History Museum and Imperial College London in the UK. He and his colleagues Prof Jon Blundy, Prof Matthew Jackson and Dr Dan Smith are leading the "From Arc Magmas to Ores" (FAMOS) research project, which involves probing deep in the Earth's crust. Their aim is to find out how molten rocks (also known as magmas) form, evolve and - rarely - end up producing ores.
Magmas are responsible for some of the largest deposits of metals on Earth. These "porphyry deposits" are formed at subduction zones, which is where tectonic plates meet and one tectonic plate bends and slides under the other. It is also where you'll find volcanoes and earthquakes. By investigating the journey of metals like copper from magma to the Earth's shallow crust, the FAMOS team are not only answering key questions about how our planet works; they are paving the way for innovative exploration tools to help mining companies find and extract new metal deposits.

WHAT IS THE FAMOS TEAM DOING, EXACTLY?

"We are studying different aspects of the evolution of magmas," says Jamie, "from where they are first generated deep in subduction zones to when they finally reach the shallow crust and crystallise."

The geoscientists are particularly interested in volcanic arcs that form above subduction zones. Volcanic arcs are curved chains of volcanoes that are hundreds to thousands of kilometres long; they are also the source of much of the world's copper. As Jamie says, if the team can work out how magmas, metals and fluids such as water are cycled through the subduction zone they will be able to "track the whole set of critical processes that may ultimately lead to the formation of very rich, but also very rare, copper deposits."

\section{WHY IS THE FOCUS ON COPPER?}

The ores that the team is investigating contain other metals such as gold, molybdenum (a useful metal in alloys) and rhenium (a rare and precious element), but copper is particularly sought after. This is because it has so many uses. Electrical wiring, water pipes, computers, and mobile phones are just some examples; and as we transition to renewable energies even more copper will be needed.

"About eight times as much copper is needed per $\mathrm{kW}$-hour of electricity generation via renewable sources than is used in conventional power generation," explains Jamie. "This is due to the extra wiring and metal components required."

\section{HOW WILL THE RESEARCH BENEFIT THE MINING INDUSTRY?}

Since most of the ores exposed at the Earth's surface have already been found, mining companies are having to look for hidden deposits deeper (up to a kilometre) below the surface. This poses many challenges. For example, how can they tell if they will find enough copper?

Magmas produce varying amounts of copper because the ore-forming process depends on a set of favourable conditions that are not always met. Some hard minerals like zircon, which can be weathered out of rocks and found on the Earth's surface, contain valuable information about the magma in which they were formed. If the researchers know which conditions are best suited to creating copper-rich ore deposits and this information is recorded in zircon crystals, then these crystals could be used as a pointer for mining companies. 


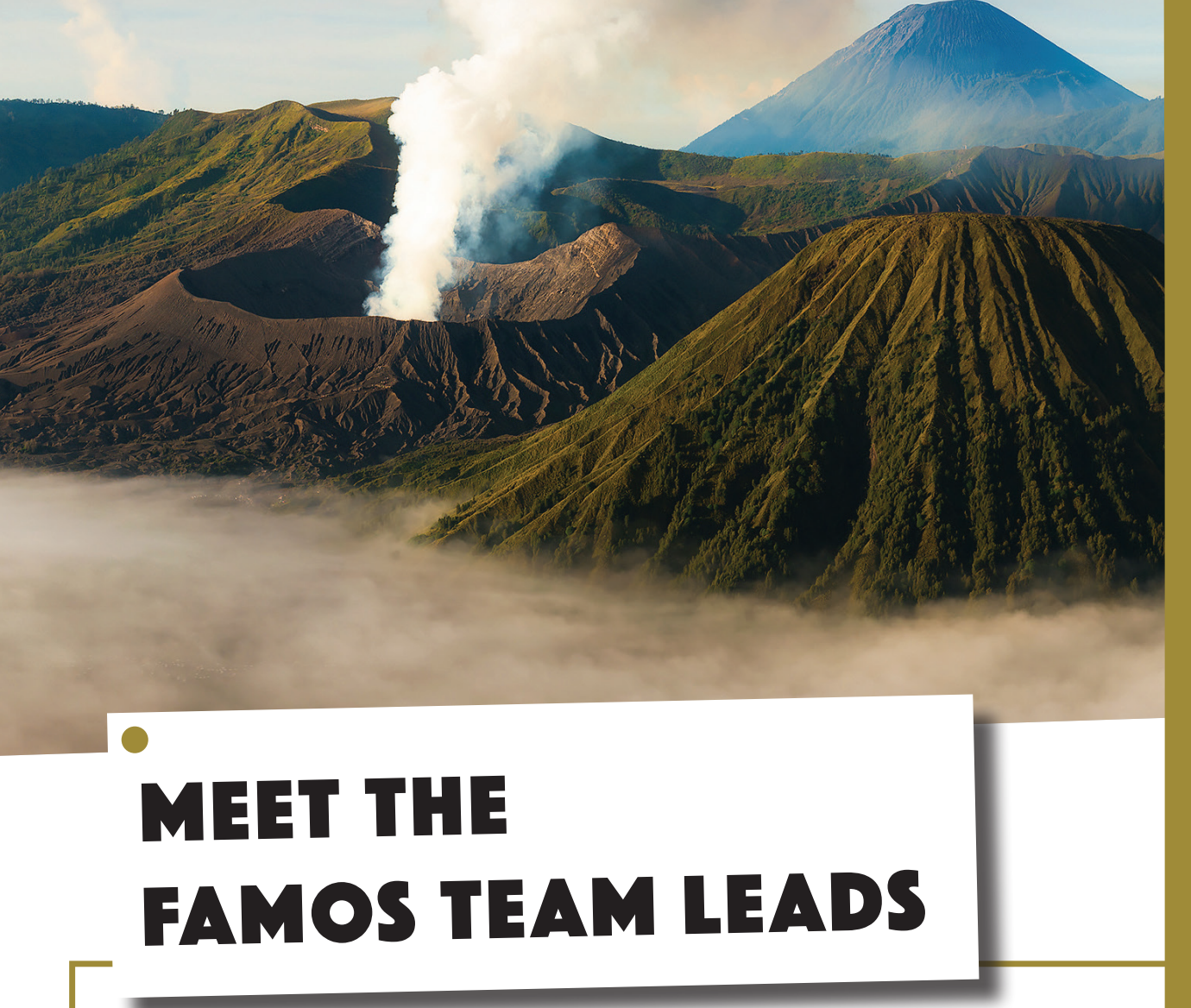

DR JAMIE WILKINSON

Research Leader in Mineral Deposits, Natural History Museum; Professor of Geology, Imperial College London, UK

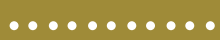

\section{FIFLD OF RESEARGH}

Geochemistry

\section{RESEARCH PROJECT}

The research, known as FAMOS (From Arc Magmas to Ores), aims to understand the processes that cause metals to be concentrated in magmatic arcs. This understanding will enable the scientists to develop exploration tools for

finding new mineral resources.

\section{PROF JON BLUNDY}

Professor of Petrology, University of Bristol, UK

I am an igneous petrologist with an interest in all things magmatic, from how rocks melt to why volcanoes erupt. I am interested to see what the similarities and differences are between magmatic systems that erupt and magmatic systems that form giant copper ore deposits.

My advice to people starting out on their career path is to study hard at school, especially the sciences. Take an interest in the world around you and be passionate about the things that interest you.

\section{FUNDER}

Natural Environment Research Council (NERC)

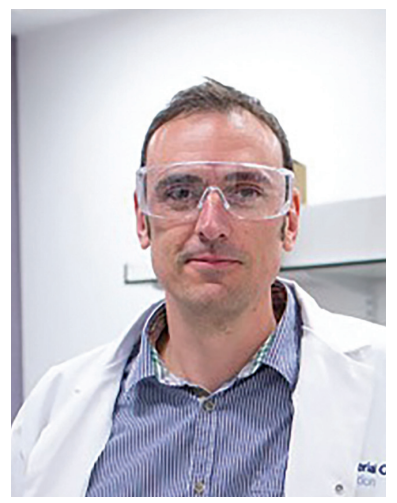

\section{PROF MATTHEW JACKSON}

Professor in Geological Fluid Mechanics, Imperial College London, UK

My role in this project is to understand and predict the fluid mechanical processes that control the formation of copper deposits. Fluid mechanics is the science of how and why fluids like water and liquid molten rock (magma) flow. The available evidence suggests that copper is dissolved in magma when it is transported from deep in the Earth towards the Earth's surface.

At some depth, the host fluid changes from magma to hot water or water vapour known as volatiles. Volatiles carry the copper to the surface, or within a few kilometres of the surface, where it crystallises to form the solid copper deposits we find today. So, flow of fluids - whether these are "magma" or "volatiles" - is of huge importance in creating copper deposits.

My advice to young people is to be curious! Ask questions. Look around you. Read! If you don't understand how something works, find out. Challenge the status quo but recognise that science needs evidence to prove (or disprove) a theory or model - an opinion, however passionately held, is not enough. And don't feel that your ambition should be limited by the school you attend, your gender or ethnicity, or what your parents do. Good science - and good scientists - spring from all walks of life. 


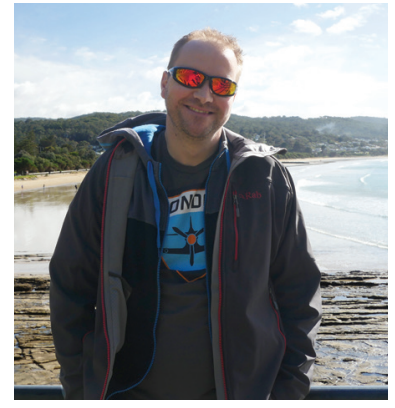

\section{DR DANIEL SMITH}

Associate Professor in Applied and Environmental Geology, University of Leicester, UK

My speciality is in magmatic-hydrothermal systems - or, more simply, volcanic rocks and the hot water and gases that flow through them. Sometimes they produce deposits of metals (gold, silver, copper and more), but most of the time, nothing.

In this project, I'm looking for "early warning signs" in the rocks that will tell us that we'll find something or nothing - before we, or colleagues in the minerals exploration industry, spend time, money and energy looking in the wrong places.

My advice is to do what you enjoy. I took up geology because I liked the little snippets of geoscience I received during GCSE study. I enjoyed the A-level and chased it at degree. During my degree I liked the chemistry components of geology, volcanoes and ore deposits.

I never picked my "next steps" based on what I thought would get me the best job or most money. I simply focused on the parts of my education and experience I enjoyed the most, and picked my path forward based on doing more of the things I enjoyed.

It's vital to get experience, though. There were some things I thought I might enjoy professionally, but after work experience - not so much! Work experience isn't just about stuffing your CV; it's about getting a feel for whether you really want to do that job.

\section{(1)

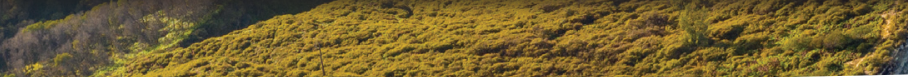 \\ . WHAT IS GEOCHEMISTRY?}

Geochemistry is a combination of geology and chemistry: it uses chemistry tools and principles to study and explain geological systems. In the past, geochemistry focused mainly on determining the different elements in rocks and minerals. In fact, the minerals and the small amounts of fluids and gases that occur in rock all contain valuable information about how it was formed. Today, geochemists study rocks to understand this information and how it could be used in

different scientific and industrial applications.

Within the field, there are many subspecialties that explore specific types of geochemistry. For example, organic geochemistry studies processes and materials that came from living organisms, and cosmogeochemistry analyses how elements are distributed throughout planets, stars and other objects in space.

\section{OPPORTUNITIES IN THE GEOSCIENCES,}

\section{INCLUDING GEOCHEMISTRY}

- The Geological Society of London has a Geology Career Pathway page that has lots of information on choosing the right course at university, available funding and links to other resources: https://www.geolsoc.org.uk/DegreePathways

\section{- Internationally, the American Chemical Society offers a fantastic} overview of geochemistry, including researcher profiles, career prospects and professional organisations you can join.

- Prospects claims that the entry-level salary for geochemists ranges from $£ 20,000$ to $£ 30,000$ annually, going up to $£ 50,000$ and higher with experience. It has a page explaining the skills and qualifications needed, and what a job in geochemistry might entail:

https://www.prospects.ac.uk/job-profiles/geochemist 


\section{ASK PROF JAMIE WILKINSON}

WHAT DID YOU WANT TO BE WHEN YOU WERE YOUNGER?

I was interested in a lot of things when I was young but always had a propensity towards science subjects. I always liked building models and creating things, but had an artistic bent too, especially in graphic design. The first careers I considered were architecture and engineering, including renewable energy well before it became commonplace. Ending up in geology and geochemistry was a fortunate accident!

\section{HOW DID YOU CHOOSE}

\section{GEOCHEMISTRY AS A CAREER?}

I went to university expecting to study chemistry or physics, or both. In the end, I discovered geology - not completely unfamiliar to me because I had been exposed to minerals and fossils as a child though my father's interest in the natural sciences, but not really a subject I had thought of as the basis for my career. So, I ended up studying the chemistry of the Earth, a truly fascinating field because of its complexity and importance for many aspects of human existence. I decided to focus on ore deposits a bit later in my career because they represent the most remarkable geochemical anomalies that exist on our planet; and also because they provide the raw materials that underpin almost every aspect of modern life.

\section{WHAT DID YOU STUDY AT}

\section{UNIVERSITY, AND HOW DID IT}

PREPARE YOU FOR YOUR CAREER? I always loved chemistry when I was young, doing home chemistry experiments, and
I decided I wanted to study chemistry or physics at university after having done them, along with mathematics, in my A-levels at school. However, I couldn't choose which I preferred so was looking for courses that combined both. The Natural Sciences Tripos at Cambridge offered one such opportunity and I was lucky enough to win a place.

In my first year I studied chemistry, physics, maths - and geology as an additional subject that I didn't expect to be able to take. I didn't enjoy physics or chemistry in my first year, but geology opened my eyes to a whole new world and I loved the fieldwork opportunities. After that I decide to focus on geological subjects through the rest of my degree (also taking more advanced chemistry in my second year) and so ended up with a geological science degree. I graduated with a BA (Hons) in Geological Sciences from the University of Cambridge.

To become a geologist you definitely need to study geoscience at university but it doesn't have to be in a single honours type of programme. I did not do nearly as much geology in my degree as others might have done, but my chemistry was strong and this stood in me in good stead later on.

\section{WHAT DO YOU LOVE ABOUT THE} WORK YOU DO?

Geology is like a hobby for me: it's endlessly interesting and it has never felt like a job. It is a very sociable subject and tends to draw like-minded individuals, so you always meet interesting and entertaining people in the course of your work. It has allowed me to visit many parts of the world, including places that it would be very hard to access through normal means. I have sampled rocks on high ridges in the Andes by helicopter, flown above grizzly bears in the remote Brooks Range of northern Alaska, seen the sun rise over the Atacama Desert and soaked in thermal pools on the Chilean-Argentinean border, more than $100 \mathrm{~km}$ from the nearest village. It also allows me to work in amazing analytical laboratories with the latest high-tech equipment, including lasers and scanning electron microscopes.

\section{HAVE YOU EVER BEEN INSIDE A} VOLCANO?

I've never climbed down inside the crater of a volcano but have visited many and walked (and skied) along their flanks. Sitting in a thermal pool surrounded by snow looking along a chain of Andean volcanoes was one highlight of my career. However, my most amazing volcano experience was sitting by the crater of Mount Yasur on the island of Tanna in Vanuatu as it was erupting, throwing incandescent rocks into the air above me, with the ground shaking and lightning crackling through the static-charged ash clouds.

\section{JAMIE'S TOP TIPS}

01 - Make sure you study what you enjoy. You never know what opportunities will come up, and enjoying your work is important!

02 - Work hard, be driven, and have confidence in your own abilities. Don't be afraid to put yourself out there to seek opportunities, and always ask questions.

03 - There is more than one route to work in geochemistry: I had more of a chemistry focus early on, whereas some colleagues come from a geology background. We all bring different strengths to projects we work on. 